\title{
O LASTRO SOCIAL E A RENOVAÇÃO LITERÁRIA EM AS MENINAS DE LYGIA F. TELLES
}

Regina Igel

Lygia Fagundes Telles, escritora nascida em São Paulo, começou sua carreira literária aos 15 anos de idade, em 1938. Seu primeiro livro foi uma coletânea de contos, com um título que ilustrava os contrastes sociais registrados nas histórias: Porão $e$ Sobrado. ${ }^{1}$ Como adolescente sensível ao desequilibrio econômico da sociedade, apaixonadamente descreveu a vida dos pobres, em sete contos sobre os habitantes dos porões, e a vida dos ricos, em cinco narrações a respeito dos habitantes dos sobrados, casas com dois ou mais andares que, na década dos trinta, eram símbolos de bem-estar financeiro.

É evidente o estilo tentativamente realista com que a escritora embarca no seu primeiro livro. As narrações de Lygia Fagundes ${ }^{2}$ em Porão e Sobrado mostram recortes de vidas sofredoras, registros de diálogos em que se revelam algumas das preocupações das classes média e baixa; entretanto, a base que sustém os contos é ainda uma delgada visão de problemas sociais e as histórias são quase totalmente alheias a qualquer elaboração artística. Apesar disto, já deixam que se descubram sinais da persoralidade estilística da escritora: tanto as personagens como alguns dos conflitos aí apresentados serão cultivados e se apresentarão evoluídos em fases subseqüentes da sua carreira literária.

Seu último romance, As Meninas, premiado pela Academia Brasileira de Letras e pela Associação Paulista de Críticos de Arte (1974), é uma amalgamação literária de temas explorados anteriormente pela escritora, como a ansiedade, a angústia e a falta de comunicação social, que preencheram as atmosferas encontradas nos romances anteriores, Ciranda de Pedra (1954) e Verão no Aquário (1963). As Meninas ${ }^{3}$ é a história de três adolescentes universitárias pensionistas numa casa dirigida por freiras, na cidade de São Paulo, na década dos 70 . Estas estudantes podem representar graduações da classe média brasileira, pois Lia de Melo Shultz é filha de um casamento entre uma milionária, herdeira de usinas de açúcar na Bahia e um refugiado de guerra alemão; Lorena Vaz Lemos é filha de fazendeiros de raízes paulistas, e Ana Clara Conceição é filha de pai desconhecido e de mãe que levava vida marginalizada. Neste romance, a autora mostra como giram, misturadas ou trançadas, uma ciranda de freiras e uma ciranda de dinheiro ao redor de uma casa de pensão onde vivem três moças que caminham nas órbitas dos seus problemas, incrustrados nas suas origens sociais e arcados de conflitos psicológicos.

Uma parte viva da sociedade brasileira é aí representada, no que diz respeito ao peculiar cosmopolitanismo paulista e à exibição de valores universalmente adotados por uma juventude sem orientação e sem direções. Nesta obra, como em muitos de seus 
contos e nos romances, Lygia Fagundes Telles retoma certas constantes, como: a idade das personagens varia entre o período da adolescência e os 35 anos; os meios financeiros da maior parte das personagens são abundantes; poucas são as personagens que trabalham para seu sustento e, quando o fazem, provocam espanto e, às vezes, até admiração, como é o caso de Mafra, de Verão no Aquário... Outros elementos explorados nos seus romances anteriores e revistos em As Meninas são a inércia, a supervalorização de problemas pessoais, traições amorosas e conflitos gerados pela falta de substância na própria existência. Registra o crítico Antonio Hohlfeld: "já se disse, e não seremos nós a discordar desta afirmativa, que o romance de Lygia Fagundes Telles fixa-se em personagens que pertencem à burguesia decadente do estado paulista." ${ }^{4}$ A distinção entre a burguesia em decadência e a burguesia em ascensão é tarefa difícil de exercer, pois o caos da transição identifica estas duas fases em muitos aspectos, mas o que se percebe neste romance é a temática predileta da escritora, que é o tratamento da angústia, que se esgarça aqui para multiplicar-se ali adiante, sem nenhuma solução que a remende, chegando, quando muito, ao cerzido. Como em Ciranda de Pedra e Verão no Aquário, a escritora não se desprende de temas que a perturbaram sempre, e traz à superfície literária de As Meninas os problemas de uma parcela dita privilegiada da sociedade, onde ela "pretende fixar, até certo ponto, alguns componentes essenciais da sociedade paulistana (poderia ser também da do Rio, que se lhe assemelha)." Acrescentaria eu que qualquer outra cidade brasileira, dilatada em seus limites em ritmo alucinante como aconteceu com São Paulo, encontraria eco em alguns dos conflitos expostos na obra. Não é "privilégio" paulistano ou carioca o espanto de uma juventude tombada em armadilhas insuspeitas no seu próprio sistema emocional, levando-a a complicações de ordem externa, como um relacionamento social caótico e inconseqüente. A autora localiza a história no rendilhado urbano de São Paulo por ser ela mesma parte da tessitura paulista. $\mathrm{O}$ embrião citadino tem estado presente em todas as obras de Lygia F. Telles, e a extração de suas criaturas nesta obra, precisamente, explora denúncias de rejeição e atração entre a flutuante classe dos arrivistas novos-ricos e a já ancorada flotilha de uma camada da população que se diz elite, ainda que mal liberta dos cheiros de maresia e senzala.

A aristocracia das terras, o clã luso-brasileiro arraigado no latifúndio podem ser representados por Lorena, que, mesmo partilhando o dia-a-dia com suas amigas, não esquece a diferença entre o café e a borra: "Tudo está nos detalhes: as origens, a fé, a alegria. Deus. Principalmente as origens.” (P. 13) Lia, chegada de uma família enriquecida com a demanda de açúcar depois da Segunda Guerra Mundial, não teve os séculos de pioneirismo e depuração da companheira, e equilibra-se entre engenhos transformados em usinas e a sociedade de consumo, desesperada por ter seu lugar na galeria dos bons, infiltrando-se em todas as camadas sociais justamente por não pertencer a nenhuma delas. Talvez houvesse alguma vantagem na sua posição balouçante, pois daí ela pode ter uma visão de conjunto que falta às outras duas: "Nunca o povo esteve tão longe de nós, não quer nem saber: ... A burguesia aí toda esplendorosa. Nunca os ricos foram tão ricos. ...Assistindo dà janela e achando graça. Resta a massa dos delinqüentes urbanos. Dos neuróticos urbanos." (P. 9) E à última camada pertence Ana Clara. É ela quem é viciada, que namora um traficante de drogas, e que está em desespero por se casar com um milionário, que lhe dará "um diamente do tamanho de um pires. . . um casaco de onça até a ponto do pé." Tudo isto sendo, no dizer de Lorena, "Poooodre de chique!" (P. 19) Ana 
Clara, cujas origens obscuras e veladas não explicam sua presença na pensão de freiras, é a personagem mais informativa da realidade da confusão urbana. Ainda que colocada entre pessoas completamente alheias à sua extração social, ela nunca pode se libertar das passagens traumatizantes de sua vida. O que as três moças tinham em comum, além de sua juventude, era o caos. Mesmo sendo cada uma delas triturada à vista da outra, mesmo com a solidariedade inata e altamente virtuosa entre elas, foram incapazes de vencer a pressão da sociedade, que as nutria de impossíveis.

Se, de um lado, este romance representa um natural avanço em caminhos já abertos no passado literário de Lygia $\mathrm{F}$. Telles, de outro lado representa uma significativa renovação na técnica narrativa brasileira no que concerne a dois aspectos: a linguagem e o ponto de vista do narrador.

A linguagem surpreende. $\mathrm{O}$ romance "é quase escrito em linguagem coloquial, com os erros sintáticos que the são normais, tanto nos solilóquios quanto nos diálogos." 6 Nougueira Moutinho diz também que "a linguagem é coloquialmente expressiva na medida exata em que os diálogos impõem o abandono das conveniências formais." romancista registra, nesta obra, o que pode ser convencionalmente chamado de linguagem culta urbana na sua prática corrente, com os desvios da gíria e do típico vulgarismo juvenil.

A variedade coloquial é aparente em descrições como estas: "Despejo mais chá na xícara. Um chá danado de bom." (P. 20, edição anotada; as palavras são realçadas apenas no presente estudo.) "Tanta coisa que precisava de revisar, ô, essa notícia, Argélia. Mas que loucura, Argélia? Argélia, putz.” (P. 129) A preocupação maior de Ana Clara é sua origem. O registro de seu nervoso monólogo revela parte de seus planos de escamotear sua história de filha natural: "Descendente de bandeirante. Original pomba... Quem é que está ligando hoje pra essa conversa de bandeirante. . . Batizo meu pai pra me casar, não posso? Caio César Augusto Conceição. Professor. ... Não tem uma porrada de universidades espalhadas por tudo quanto é canto?" (P. 72) O amante de Ana Clara, rapaz viciado em drogas, revela um linguajar típico de quem tem preocupações mais importantes do que falar como pedem as regras estabelecidas pela gramática: "Queria comprar uma ilha. ... Tem ilha por ai de dar com o pau. ... Podemos morar num troço assim besta como a Irlanda. . . . A gente não veio pra se aporrinhar." (P. 35)

A cultura francesa também penetra pelo vocabulário das universitárias, revestida de um brasileirismo que lhe dá uma certa qualidade pitoresca, como se faz com a transposição de Je m'en fiche e bouleverser: "Você acha pouco. Eu me ficho com isso mas preciso ver se ele também se ficha." (P. 18) "Ana Clara vai buleversar a coitadinha." (P. 19)

Das três, é Lorena quem se mostra mais cuidadosa com a linguagem, revelando uma busca de aprimoramento que lhe viria do ambiente sofisticado da sua família. Ao pensar em Lia, aquela que tinha o namorado preso por atividades políticas, ela diz: "Está furiosa comigo, ai meu Pai. Mudou tanto, coitadinha. Quer dizer que Miguel continua preso? E aquele japonês. E Gigi. E outros, outros, estão caindo quase todos, que loucura." (P. 54) E quanto à viciada Ana Clara, Lorena revela: "Obriguei-me a verdadeiras práticas de caridade cristã para aceitá-la, mas agora sinto falta dela quando some. Ana, a Deprimente. Deprimida e deprimente." (P. 54) Lia e Ana Clara, por terem sido menos reprimidas na 
sua formação, distribuem uma substancial coleção de palavrões, principalmente a última delas. O registro vocabular trazido pelo romance o coloca, num plano histórico-literário, como um retrato realista de uma sociedade apressadamente industrializada e, por isto, caótica, cujo sistema escatológico de comunicação reflete uma neurose cumulativa diária.

Ao fixar uma linguagem abusada, muitas vezes gratuita e, ao mesmo tempo, hermética, Lygia Fagundes Telles mostra uma nova face da sua ficção. O escritor Edigar de Alencar comenta que "a romancista envereda por novos caminhos e se toma de ousadias que na melhor das hipóteses poderiam comprometer-lhe o passado vitorioso de escritora clássica, no bom sentido do termo." ${ }^{\text {N }}$ Na melhor das hipóteses, no entanto, a escritora não parece comprometer nada. Pelo contrário, ela se põe a par com os tempos em que vive, numa sociedade em que sobrevive. Segue a pulsação frenética de roldanas metálicas, de registros psicanalíticos e contas bancárias. Como escritora vigilante, cumpre com sua chamada pessoal.

O segundo aspecto da renovação trazida por As Meninas diz respeito ao ponto de vista adotado na narração. Para Antonio Hohfeldt, "o ponto de vista da narração é tríplice, por vezes pode mesmo um fato ser repetido três vezes seguidas, pelas diferentes personagens, de forma que ao leitor caberá a opção final. ... embora exista um quarto ponto de vista, o da narradora que se refere aos fatos, coletivamente, ela o faz de modo eqüidistante, sem decidir-se por uma ou outra alternativa." $\mathrm{O}$ mesmo foi anotado pelo crítico Elias José: "Uma das mais positivas conquistas estilísticas de Lygia Fagundes Telles, já experimentada em contos anteriores, mas não de maneira tão feliz como neste romance, é a variedade do ponto de vista narrativo. . . Narrador objetivo se mistura com narrações subjetivas das personagens. ... Não há apenas um emissor, o escritor narrador, onisciente e onipresente, mas cada uma das meninas mais o narrador quase na sombra delas." 10

No dinamismo mostrado pela narradora, não se dissimula a influência da velocidade que caracteriza a cinematografia. Esta obra está entre os poucos romances brasileiros que utilizam tão abertamente uma técnica propícia à filmagem, e particularmente inclinada ao tipo de filmagem que faz uso da câmara apoiada ao ombro, seguindo os menores gestos dos atuantes. Já em 1922, a revista modernista brasileira Klaxon recomendava "o aproveitamento das lições do cinema. . . O cinema que gera toda uma gramática e toda uma nova sintaxe, toda uma transformação da linguagem de rara eficácia para a compreensão e captação dos sentidos do homem." 11 Respondendo ao movimento, "de técnica cinematográfica será o romance de estréia de Oswald de Andrade,"12 e na linha de uma tradição iniciada em 1922 e esporadicamente retomada, surge As Meninas. O primeira capítulo já é uma amostra deste dinamismo cinematográfico, com enfoque no narrador em primeira pessoa, Lorena, que pensa: "Sentei na cama. Era cedo para tomar banho. Tombei para trás, abracei o travesseiro e pensei em M.N.” (P. 3) Logo a seguir faz-se a intromissão da narradora-escritora, sóbria, cuidadosa com o estilo, seletiva no vocabulário, o que ressalta, por oposição, a violência da linguagem das personagens. Descreve a chegada da segunda menina, Lia, e num movimento repentino, é o pensamento desta personagem que se abre: "Estou demais aperreada para ficar ouvindo sentimentos lorenenses, ô Miguel, como preciso de você." (P. 8) Lia, com seus vagos sentimentos de justiça social que não sabe canalizar, do camarote da sua fortuna, pensa em seu namorado 
com tintas emocionais, exibidas pelo foco da câmara empunhada pela ficcionista: "O seu sofrimento, Miguel. O meu agüentaria bem, sou dura. Mas se penso em você, fico uma droga, quero chorar. . . A burguesia ai toda esplendorosa." (P. 9) O afastamento da narradora para benefício da personagem, que mostra abertamente sua divagação mental, aproxima o texto literário da fotografia sonora, quando o pensar do ator na tela é revelado por uma voz interna, se for possível chamar assim ao recurso utilizado na sonoplastia, ou seja, a voz gravada que informa o espectador do pensamento corrente do ator. Todo o primeiro capítulo se faz com saltos entre pensamentos e expressões verbais de Lorena, Lia e a narradora-escritora, um prelúdio para o restante da obra, que minimiza as descrições na valorização da amostra dos atos. É este o ponto que mais caracteriza e aproxima este romance de um filme, pois o dinamismo visual do cinema é paralelo à movimentação de uma página literária na ilustração de divagações sem fornteiras, as quais transpassam umas às outras em associações de idéias. Por exemplo, quando Lorena se descreve no banho, ela viaja mentalmente por cenas já acontecidas, e sucede o que em cinema é facilmente alcançado com superposição de imagens: "Entrei na banheira vazia, deitei-me no fundo e abri a torneira. O jorro quente caiu no meu peito com tamanha violência que escorreguei e ofereci a barriga. Da barriga já pisoteada o jato passou para o ventre. . Fechei os olhos quando Felipe cruzou e recruzou meu corpo com sua moto vermelha, Felipe o do blusão preto e moto." (P. 14)

Embora recursos como flashback e associação de idéias sejam comuns à obra literária, o que os faz similares aos recursos cinematográficos, nesta obra, é o abrupto, o inesperado, a velocidade da eclosão de cenas e pensamentos. O leitor topa com uma movimentação que empresta às personagens e aos seus problemas uma dimensão fluida, o cinema e esta obra, é notável o intercâmbio entre a arte do movimento, própria da cinematografia, e a arte poética, da literatura. Como dois focos de luz convergindo para um palco, que seria São Paulo, uma trança de vidas jovens é entreaberta, deixando que se veja um emaranhado difícil de ser desembaraçado. A narradora empunha uma crua luz sobre três vidas embaralhadas, enceguecidas e quase derrotadas. A não-interferência da autora na sua própria ficção coloca As Meninas como uma resultante brasileira de coordenadas universalmente atuais. $\mathrm{O}$ tema do romance e os demais elementos de renovação literária aqui discutidos levam o último trabalho de ficção novelesca de Lygia F. Telles a representar todas as São Paulo que possa haver no mundo do progresso, ainda que seja um progresso desprovido de evolução.

Department of Spanish and Portuguese

University of Maryland - USA 


\section{NOTAS}

${ }^{1}$ Lygia Fagundes, Porão e Sobrado (São Paulo: 1938).

${ }^{2} \mathrm{O}$ sobrenome Telles foi agregado por ocasião de seu primeiro casamento; a escritora o conserva como nom de plume.

${ }^{3}$ Lygia Fagundes Telles, As Meninas, 6. ${ }^{\mathrm{a}}$ ed. (Rio de Janeiro: Editora José Olympio, 1974). As páginas marcadas no decorrer deste estudo se referem a esta edição.

4 Antonio Hohlfeldt, "A nova perspectiva de As Meninas," Correio do Povo, 4 de maio de 1974, p. 13.

5 Almeida Fisher, "As Meninas," Diário de Brasilia, 11 de abril de 1974, p. 12.

${ }^{6}$ Almeida Fisher, idem.

${ }^{7}$ Nougueira Moutinho, “'As Meninas' de Lygia Fagundes Telles," Folha de São Paulo, 6 de janeiro de 1974, p. 9.

${ }^{8}$ Edigar de Alencar, "As Meninas," O Dia, 7 de abril de 1974 , p. 16.

${ }^{9}$ Antonio Hohlfeldt (V. Nota 4).

${ }^{10}$ Elias José, "Anotações sobre 'As Meninas,' "Minas Gerais, Suplemento Literário, 18 de maio de 1974 , p. 9.

${ }^{1}$ Mário da Silva Brito, Introdução à reprodução de Klaxon, Cinqüentenário da Semana de Arte Moderna (São Paulo: Livraria Mart ins Editora e Conselho Estadual de Cultura, 1974), s.p.

12 Silva Brito, idem. 